\title{
GOVERNANCE, DEMOCRATIC INNOVATION AND CIVIL SOCIETY ORGANIZATIONS, AT THE END OF THE MODERN STATE
}

\author{
Cutberto HERNANDEZ-LEGORRETA \\ La Salle University/ Mexico \\ cutberto.hernandez2@lasalle.mx
}

\begin{abstract}
The exercise of politics among its actors vindicates the citizen role of the population in today's societies and it gives the ability to participate politically within the State. From the perspective of international financial agents -as financial organizations or banking entities - such participation is settled since some systems, such as governance, are adopted, and it implies attention and solution to social and political demands. Governance involves running politics on behalf of a better government, re-signifying the concept of democracy from and for the market economy perspective, through democratic innovation practices. For its part, the civil society organization (CSO), in terms of governance, is understood as non-governmental organizations (NGOs). It implies being incorporated into the dynamics of the administration of political work in an apparent horizontality within its actors, where its mechanisms operate equally by government, business and civil society. This participation scheme seeks to justify it from liberal democracy, by creating mechanisms and institutionalizing it. Methodologically it allows to understand its dynamics within the governance space. Its existence and need to take control of the policy is reviewed by pushing it into a new representation by incorporating concepts such as horizontal governance and good governance, used to legitimize this new way of administering political work. This process is legitimized by creating the
\end{abstract}


conditions to justify new mechanisms of control through the institutionalization of democracy with concepts that strengthen it such is the case of democratic innovation in which its first form is precisely governance.

\section{Keywords}

Civil society organizations; democratic innovation; good governance; horizontal governance; policy administration

\section{INTRODUCTION}

This dissertation seeks to plot the arguments aimed at providing the elements for an analysis on governance, democratic innovation and civil society organizations, and their role in the quest to deal with the recurring crises of the state in the aftermath of the Modern State, it is required to be imaginative in addressing the concepts. Some freshness is demanded when offering a series of proposals for the interpretation of the problem, such is the case of inequality as an effect of the "de-modernization" of societies. It is necessary to explore the relationship between concepts on: civil society organizations; its relationship in some way with governance practices sometimes translated as democratic innovation.

The main idea is to prove that the practice of governance can be presented in a pragmatic way, rather than its development, as a result of theoretical application in a real space. It is considered to be present from the beginning, as defined by the concept of governance: new actors begin to participate in the decisionmaking spaces of governments. Such is the case of the incorporation of civil society organizations in the decision-making spaces of governments based on the experience of horizontal governance and is further reinforced by acting in accordance with the "good practices" developed by the new actors in incorporate democratic innovation applications into your work.

This paper is based on the construction and development of the context and definitions of fundamental concepts such as governance and democratic and social innovation; it is about placing the reader in the context and definitions of 
these two basic concepts. As can be seen further in the first years of the last third of the last century, there was constant concern about the governance and efficiency of States, in close relation between the size achieved by their institutions - contradictorily - and the growing demand for attention of social demands. At the same time, greater human and economic resources from the State were required.

The neologism "governance" has been used since 1980s and an exponential increase in it use can be seen up to be present in a good number of government reports. According to Krahmann $(2003,332)$ who gives us a continuum in relation to the dimensions of the concept. As a result it can reach a range functional where the practice is assumed in "a single issue" as in the case of "horizontal governance".

The next thing to address is the construction of social democratic innovation from the good governance model - for its part, the Civil Society Organization (CSO) in terms of governance is understood as non-governmental organizations (NGOs). It implies being incorporated into the dynamics of the administration of political task in an apparent horizontality of its actors, where they operate their mechanisms equally by government, business and civil society. This participation scheme seeks to be justified from liberal democracy by creating mechanisms to institutionalize it and qualifies this new relationship and incorporates it into the concept of "democratic innovation" which is supported by the technological development of the "digital government", and the incorporation of entrepreneurship under the figure - at times - of "regulatory bodies" in an attempt to give the idea of societies increasingly consolidated in democratic practices through innovation. In this scheme any demand made from the public space quickly loses legitimacy. The new reality of an increasingly "desocialized" State, far from reducing the margins of inequality in any of its forms, is deepened, by making it invisible, based on a new contextualized relationship based on the interests of the economy of market.

The narrative begins with a theoretical contextualization of civil society organizations, approached from different theories, explaining their role and function within the modern state. Methodologically it allows to understand its dynamics within the governance space. A review of governance is made, its 
historical evolution and justifications in the midst of globalization, and the demand of market economies are explained. Its existence and need to take control of the policy is reviewed by pushing it into a new representation by incorporating concepts such as horizontal governance and good governance, used to legitimize this new way of administering political work. This process is legitimized by creating the conditions to justify new mechanisms of control through the institutionalization of democracy with concepts that strengthen it, such is the case of democratic innovation in which its first form is precisely governance.

\section{REFLECTIONS ON THE MODERN STATE CRISIS: GLOBALIZATION AND MARKET ECONOMY}

Despite the progress made in various fields of science, a good part of contemporary societies are overwhelmed by discouragement, and it can be noticed in the mass migration, structural violence -expressed in different waysand the negative impact on ecology in different levels. Although it sounds contradictory, diseases and epidemics that would have devastated entire populations in other time are defeated today. Information societies have been accessed, where technological advances continue to amaze their impact on our daily lives. Engineering, meanwhile, has brought new satisfiers to our lives. More and more communities live in democratic societies.

Discouragement then seems unjustified, it is not possible to understand the reason why, despite the progress made, there is no progress in reducing inequality and poverty, eliminating corruption and organized crime. The state crisis and the ungovernability of their societies unfortunately continues to be a reality with no apparent solution. Progress in democracy has not been enough, it could be said that we are facing a "progress crisis" (Friedmann 1977). It seems that the notion of "being what is done" has been lost now deprives a notion that is reaffirmed day by day, more and more we assume behaviours created by organisms that not even most of the time we know exist. There are those who increasingly are driven by the wave of information processes and goods 
demanded by the crowds. However, some others are given the task of rebuilding a community that protects their identity. However, the vast majority are faced with the dilemma of pretending to belong to one or the other of the scenarios that opens before them.

It is often accepted without regard that modern society permanently favoured the correlation between institutions and individuals, as is considered as the unique and universal value of a rationalist conception integrated by the worldsociety-individual triad, a relationship that was questioned and it was claimed of being the generator of the imperfections of the modern state system that has to be corrected. Towards the final third of the last century, the driven idea of popular sovereignty began to be questioned, initiating a new project whose main objective was to break up the notion of a community of free and rational citizens built from the spoils of the old regimes based on tradition or divine law began then, the implementation of the modern state model.

Modernity, since its inception raises the dissociation between the accumulation of natural laws and the cosmos of being, in its environment originated the rupture of the world of religion, which at the same time was rationalist. The meaning was then translated into the rupture of the religious model, giving way to a world of the rational and the modern state, in that context the incomprehensible denial of the autonomy of the decision is affirmed that ultimately that of morality itself. It gave way to the idea of natural law, with it to the claims of rights, already present in American and French societies of the late eighteenth century. In them the affirmation is based that the social order not only synthesized the general will, but at the same time it was a principle that did not necessarily reflect at that time, nor now the social reality: equality.

Modernity can then only develop if a principle of order and integration is added to bourgeois individualism (Touraine 1997, 33). In the idea of society during early modernity, the existence of a rule of law was foreshadowed as a central axis. The new state was formed by entities that functioned on the basis of "first time" universalist principles and deep roots based on the individual's individual.

The subject conceives himself capable of reasoning and therefore aware of the existence of rights in his favour, but also of obligations and duties. Within the 
new system, each individual submits to laws that respect the legitimacy and independence of their private life. This ensures the consistency of society within the secular modern world, this gives way to the general interest that ends up becoming the supreme norm. Thus, education and law in parallel ensure the existence of individual and social spaces, giving rise to the game of mirrors that is sought between the individual and society.

Modernity in its classical model was formed from the coincidence of three social factors: rationalization, moral individualism and the functionalism of new institutions (Touraine 1997, 35). This last element is considered fundamental for the system. For its part, the preponderance of the market in the new economic system was largely driven by the replication of a growing private life in society. This condition is only overcome from the construction of the modern idea of society, idea that goes beyond the mere social or political groups of nation or city. Historically it transcends outward, sometimes in the form of hegemony.

As a result of this relationship, it is affirmed that the individual reaches his truly human being at the moment in which he participates in public actions and decides to participate actively in the decisions that affect society as a whole. The human ideal referred to then is the citizen. With its construction, the impulse that from that moment on civil society acquires, as a political entity with transformative capacity within the established institutionality, is given rise.

In the same context, social and political institutions are identified as precursors of the dissociative abolition between public and private. Since the time of the Enlightenment, the mercantile economy has been identified as responsible for the social behaviours that distance the person from his moral sense, charity for the other and respect for what we would define today as human rights. Since the 19th century, the idea of progress has been overwhelmed to this day by the cult of metal, the building of ideas around nationalism, the acute emergence of the class struggle accentuated by rising urban precariousness, as well as of working poverty (Touraine 1997). In the same way, workers and capitalists saw in the "progress" the same movement from which they justified demands while identifying themselves as adversaries of each other and mutually taking responsibility for blocking progress. 
The classical model of the modern state began to present certain fissures that provoked its questioning since the mid-nineteenth century, at that time, characterized by constant confrontations in industrial societies. What translates into a decline in the model itself, can be explained from the demand for increasing autonomy by the economic forces in clear breaking of the rules and priorities of the states. The reconfiguration of the modern western world left aside the dominance of the prevailing political, to give way to the control of society by the market. It can be said then that from the beginning the spaces of the political are settled by the economic.

According to Simmel (1987), the interest of the business world, as well as the capitalist profit and the money itself, caused the destruction of the notions of the established order in which the modern state was initially built. It would have to be valued then, as far as the idea of society was affected by the preponderance of the economic and the technical, as well as by the exaltation of individualism. In this way, it is possible to understand the efforts that historically some part of the civil society has tried to return to the political order its centrality and the control of the laws both to the economic activities and to the other aspects of the private life of the "society". The struggle to subordinate political power to the interests of society in its form of social actors has meant countless social movements, sometimes with relative successes (Holloway 2002).

However, economic policy has progressively replaced constitutional law as a central principle by modifying institutions to allow the market to dictate its laws without apparently affecting it, because in fact it demands its existence within democratic discourse. At the same time, consider the validity and solidity of the rule of law as capable of maintaining a dual balance of Modernity between industrialization and technological progress at any stage of personal freedoms and public spaces. The approach is only possible if it is faced with new forms of civil society organization, derived from a complex reality developed from profound modifications in the liberal system, currently in the form of governance (Espejel 2013, 21-36).

At present, so far from the first two decades of the twenty-first century XXI, imaginative answers to the problems they pose are necessary: how to understand the world after a twentieth century marked by social and political 
opposition against a political order marked yes by democracy, but with a growing social justice debt? On the other hand, some say ${ }^{1}$ that the dangers of a racial, nationalist, ethnic or religious identity have disappeared. Giving way to a political order guided by the attachment to the institutions (Fukuyama 2015), without clarifying that the clash in the framework of market interests against world representations framed by expressions of diverse cultural identities has taken place. On one hand, the solvency of the economy along with its institutional frameworks lies in its unity, on the other the segmentation of cultural identities causes the separation of two different conceptions, one based on technological advances and the market, the other that of cultures with their instrumental cognition based on evocation grouped in relation to the "other". This segmentation or dissociation has been called "de-modernization", meaning that rationalized creation's duality and internal autonomy of the subject by the idea of the national society, at the same time defined from the breaking of the union between freedom proper and solidarity efficiency (Touraine 1977). The notion of postmodernism has long been presented as the useful instrument, to interpret the crisis and the end of the rationalist model implanted from the Enlightenment, to try to understand the crisis that the modern state is going through today. However, we continue to question the idea of not being able to prevent "de-historized" cultures from enclosing themselves in turn becoming cultural sects. That goes against the rationalized idea of a world based on the reproduction of democratic societies.

On the other hand, everything seems to indicate that societies in the midst of the crisis of the modern state are directed to seek only their capacity for action within the market, to understand the social behaviour of consumers in globalization. Hence, postmodern thinkers seek to confront those limits in order

1 For authors such as Fukuyama, Occidental prevails everywhere: market economy, parliamentary democracy and cultural tolerance are part of that world. Its interdependence, as the only possible social model, is the reference, after the communist model has collapsed. On the other hand, Huntington, on the contrary, postulates the existence of a world dominated by cultural or religious wars, fundamentalists facing nations or social classes. 
to address problems with a broad view. That is, those who propose the study of an organized civil society and the necessary construction of a new citizenship, ready to face the crisis of classical modernity. With the intention of reducing the disorderly atomization of the interests of the communities, their imaginary and their signs within the framework of societies determined by the market. As a consequence of this "demodernization, the agglutinating elements of societies, dissociate causing the mechanisms of exchange of their cultural experiences to separate, generating what is sought to remedy, that is, the crisis of the State.

It is difficult to believe that a world mediated by trade is subordinated to norms that organize its operation, as much as it is difficult to admit the segmentation of identities and real multiculturalism. But before trying to overcome this dissociation within modernity, it is necessary to recognize the impact caused in the heart of today's societies where citizens are a fundamental part of the changes within the modern state; where the role of citizenship whose main and greatest strength is the definition of itself is claimed. His own self-construction from the affirmation of the existence of citizenship only from the recognition of the right as a citizen to have rights.

It is necessary not to fall into a melancholic vision of "de-modernization." It is necessary to recognize the advantages and risks that imply the fall of social conciliations and the previously affected policies between economic activity and political and cultural experience. As the definition of stability in the processes of social controls progresses, unfortunately the risk of atomization in State structures is also corrected. Hence appears the urgent need to create governance mechanisms in the face of such a crisis of governance of the modern state.

The context of the system in which the international market is developed is necessary to understand the theories that underlie it. From their point of view, the State is seen limited in its economic dimension, putting aside the social dimension of it to limit it to being a homo œconomicus. From this, the eco-space conducive to the development of the entire current social system is constructed, that is, globalization, where the free movement of goods, services and capital is imperative, where it is more than evident that it cannot be allowed to be subject to any form of constraint. 
In this context, political boundaries should abolish them and concepts of nationality should disappear in favour of world citizenship, this is how it has been read in the literature that legitimate all forms of world governance, or at least that was the intention of the report of the Trilateral Commission on the governance of democracies of 1975 (Requena 2014). It is not surprising that at present the concept of the international has been replaced by the global, it is a very subtle change amid the homogenizing culture that the current market system requires. People become global, uprooted, replacement, disposable individuals (Touraine 1997).

On the political level, as expected, the modern state is designated as the enemy of the current hegemonic system: the market. From the traditional position of society, the role of the market is subject to sovereign conception. Currently, the economy in the form of a market breaks into the first place, giving rise to the modern state being stripped to such an extent that the intention points to its fading in favour of a sovereign market. In politics you cannot forget there is a priority choice over all others and the market is no exception, in it is the "common good" that should prevail over the interests of individuals.

For those who prioritize market interests, social relations must be commercialized to the degree of reification in order to be considered as part of the system. The private is privileged over the public by initiating a contradiction, where every culture, not aligned with the interests of the markets acquires an unequal differentiation, is only of interest if and only if it can be part of that market. Nothing that is not profitable can acquire enough interest to be preserved; this can shed some light on possible explanations to the migratory phenomenon that, without being the subject of this essay, cannot be ignored.

The Modern State once protective of the "common good" is undermined to become a "management state." Since then, it is only called to endorse the basic scenarios for the development of the free market in its new dimension, the international one over the domestic market. The State, then, is not called upon to assign a model, much less, an idea of the "common good", on the contrary, it only deals with setting up systems based on governance. In other words, create the necessary conditions for the implementation of governance, whose model is ultimately based on neoliberalism that takes on the form of a market. The 
objective is clear: to control the political space and embed its operation towards the interests of the system that seeks to reproduce itself.

Politics and the economy cease to serve two different rationalities in this way, they are unified under a single economic hegemony. The modern state then works according to the rules and logic of the market under the formula of governance (Ibañez 2012). The rest of the administration an political power demands operate in the management governance scheme that takes its elements from the "capitalist", "modern" model, directed on the new formulas "models of management" basis, with agreements, proposals, appraisals of results, commissioned by objectives, promotion of autonomy, delegations of power, flexibility of the lines of attribution and their constraints on collaboration and accountability, their emphasis on performance and competitiveness, etc. (Ibañez 2012).

The answers seem to be within the State reform processes that include intense decentralization programs that require multilevel public administration professionals: national, sub-national, regional and urban, to name just a few. While a variety of social groups are managed by themselves, from the decline in state control (most often involuntary). Governments, through their major laws, have sought to determine functions and sources of legitimacy to organize societies in new ways that meet the needs of the market. In spite of the legal and constitutional conceptions, the success of the democratic administration depends as much on the practices of those values, as on the managerial forms that are used to administer public affairs. We are facing the emergence of governance as the new system that seeks to oxygenate, when not to save the modern state in the midst of the generalized crisis in which it finds itself (Zenteno \& Osorno 2015). 


\section{CIVIL SOCIETY ORGANIZATIONS AND DEMOCRATIC / SOCIAL INNOVATION}

For the incorporation of concepts such as innovation, it is necessary to reiterate the importance of governance, to understand the current state of affairs regarding issues such as inequality. In addressing the role of social and democratic innovation, the responsibility of the State is usually left aside, justified by the application of sectoral policies of a social nature. It reduces public policies in this way to an application of mere effects and products of the mandates "agreed upon" by governments.

As is often the case with any concept under construction, academic consensus is not yet achieved, the advantage is the flexible phase in which it is located, which allows democratic innovation to be considered as the result of a cultural environment of real and concrete communities, the following leads to the process of identifying variables and social action processes to boost operations that produce innovation within a specific cultural context (Hernández-Ascanio et al 2016, 169).

A large number of authors point out that every innovative process seeks to cover a need that has not been met or is poorly met, hence innovation seeks to address it through new and creative ways (Mulgan 2006, 145-162). As an object of study, innovation moves transversely when studied by different disciplines such as politics, sociology, economics and philosophy, without letting the organizational field and the market pass. Among the basic references is its close relationship with governance, hence its location in the economic perspective of the Organization for Economic Cooperation and Development, who states about innovation in the Oslo Manual (OECD 2008), is not an aim in itself, rather in a medium that allows the growth of production and productivity. It is clear that for the OECD it is understood in relation to the increase in the competitiveness of companies, the reduction of their production costs and their presence in the markets, arising in the midst of the globalizing process of neoliberal policies that took advantage of public policies implemented to lose weight the State. Even when said thinning directly affected the population used to test these policies. 
On the other hand, it seeks to base democratic innovation from a spectrum far from economic and technocratic theories, which simply do not consider aspects such as social cohesion (Moulaert et al. 2010).

The emergence of the economic and financial crisis in 2008 meant restrictions on public spending that resulted in the precariousness of the welfare state. This situation has allowed the reflection giving rise to spaces of social action where neither the market nor the State have managed to cover adequately. The historical moment to which reference was made gave rise to the internal discussion of the implementation of actions of the participation of organized civil society. It is necessary to reconsider the need to incorporate governance mechanisms designed from the perspective of an innovation, aimed at meeting the democratic and social needs of the communities.

Conceptually, democratic innovation is conceived as the actions and practices that put democratic values in favour of well-being, quality of life, or the proper functioning of the public or private services received. That is, ultimately, innovation is everything that creates democratic and social value through its practices. It seeks to solve a social or democratic problem in its efficiency, the sustainability of society as a whole and not only in favour of individuals.

This leads us to ask the following question about democratic innovation: what role does democracy play in social changes? Through the difference and decrease in the space occupied by politics, various subsystems established in a relatively autonomous, explorable and relevant manner can be explored within the decision-making structures of the State. This implies the preexistence of political conditions within the market's own sphere of competence against the problems that society is facing in its different areas after the application of adjustment policies, which led to what Touraine points out as the "demodernization" of the State (Touraine 1997, 54-56).

Democratic innovation is a developing status, increasingly important in some regions of the world, mainly Europe and Latin America. This type of innovation involves placing people at the centre of the action, to be the engine of the model by positioning themselves as subjects of innovation. By submitting to governance actions as a political and management procedure, in decisionmaking, by promoting citizen empowerment through market regulation, it 
means being able to drive the government's responses to social welfare. According to Brunner (2011), democracy has historically been the political epicentre where there have been a series of changes and social innovations. Today, the above is evident by assuming more and more, the form of political organization that will ensure the change "of" and "from" societies. It is worth asking about what is the role of governance in this process of "administering politics" to reconcile the genuine interest of societies to participate in decisionmaking from the political sphere and not merely as an administrative process?

Innovation, how a process of a political nature, generally associated with democracy is used to balance relations between political and private institutions by influencing their decisions. If the approach raised by Echeverría $(2008,37)$ is considered as the main axis, "[...] modernity is an unfinished project because its changes and its novelties always have the need to consolidate initially in the tradition", it should be clarified that the concept of Social innovation, like that of governance, as mentioned before, is under construction, for which reason it has varied according to different historical contexts.

On the other hand, as Abreu $(2011,25)$ points out, "innovation [...] as a complex and multidimensional phenomenon has quickly become a political-social discourse", it is important to point out that innovation practices related to qualities of collaborative economy, corporate social responsibility or social enterprises does not necessarily respond to social problems. The interest is closer to what is indicated as "innovation practices" related to social and environmental problems, typical of societies in the midst of systematic vulnerability, which requires developing imaginative practices aimed at solving them (Morales 2008, 23- 24).

Modification in the process in decision making is not enough. If you want to talk about effective democratic innovation, they should also be observed in the form of applicable public policies. It does not mean that they are not done, however, it goes without saying that in practice the market criteria prevail, for example, we have programs to combat poverty or the creation of infrastructure, where they are served according to the concentration of demand in a context of marking. However, it is to be recognized that the processes have improved somewhat. Currently, we can see cases where people or entities related to the development 
of programs derived from public policies have been incorporated. In them, CSOs acquire relevance, such is the case of the participatory budget (Bloj, 2009), in which a greater responsibility for it is sought. In this sense, efforts should focus on building trust towards institutions as an exercise from governance. In parallel, traditional power centres should ensure their consolidation to remedy their stumbling blocks (Goldfrank 2006, 20-22) and readjust participation mechanisms, by ensuring their real consolidation and not just nominal.

On the other hand, the implementation of governance mechanisms requires that citizens and commissioned government bodies be responsible for the results achieved. The duo is considered appropriate: control-evaluation should be part of the "good practices" of governance. With the intention not only of a new way of exercising power, by sharing it, but of making the operations of governments efficient, - in that lies its importance - by consolidating greater quotas of legitimacy within the institutions involved. This would represent the timely deactivation of probable social contingencies.

However, when incorporating the previous concepts, that of democratic innovation, it is necessary to note in the approach addressed the need to make clear the strategic importance of governance, being the vehicle that justifies the current state of affairs regarding Inequality State responsibility is neglected through social sector policies, reducing to mere effects and products of mandates "agreed" by governments. Faced with the inevitable globalization and government systems subordinated to the international market through the implementation of policies designed by international financial organizations.

Innovation, as a process of a political nature, generally when associated with democracy is used to balance relations between political and private institutions by influencing their decisions, in a social scheme based on knowledge. If it is considered as main axis the raised thing by Echeverría $(2005,34-36)$ "that the modernity is an unfinished project because its changes and its novelties always have the need to consolidate initially in the tradition".

On the other hand, at the beginning of the last third of the last century, a constant concern was the states in crisis, it was attributed to the size reached by their institutions - contradictorily - and the fear of the apparent progressive 
growth of social demands. At the same time, greater human and economic resources from the State were required.

To better understand and deal with this situation, the Trilateral Commission was created. Its fundamental objective was to evaluate the effects of the "worrying relationship" between the State and democracy (Requena, 2014, 3738). He served as a reference document and analysis, while still being the object of direct criticism of the role that the State and democracy then played in the geographical regions of interest to the Commission. It would be only a decade later when their recommendations were implemented directly in economies such as the United States and the British, and then implemented in the rest of Latin America and other developing regions, but not before experiencing directly in their laboratory real, as happened with the Chilean case, after the 1973 Coup.

The report addresses as an object of study the difficulty of governance in the different western states, as a result of the increasingly widespread distrust in the institutions of democratic regimes. The apparent ineffectiveness of their governments was evidenced by not responding to social demands. The same report shows that democratic states had low quality regulations. The institutions of their governments were ineffective in showing a situation of imbalance due to the exponential amount of unsatisfied social demands. The really surprising thing is to discover among its explanations of the phenomenon, an overload of demands, the result of the "excess of democracy" and the imbalance conditioned on ungovernability (Requena 2014, 45).

Governability does not have a direct link to governance according to the report, since the theoretical arguments about it had not yet been developed - currently under construction. It is undeniable as its recommendations were implemented through economic adjustment and political participation of its new actors. It required the implementation of a type of management that will legitimize it, hence the need to create a model, called: governance. At that time its prefiguration can be assumed as a democratic innovation, which also assumes the characteristic that distinguishes it, that is, the "administration" of politics. Towards the end of the 20th century, a group of economists and politicians sheltered by international organizations, set out to devise the creation of 
innovation systems based on the governance model. The result proposed an apparent democratization of the system by pointing out the need to design the horizontal governance scheme. This scheme has among its characteristics is the "inclusion" of a new actor in decision making and proposes a horizontal relationship between: government-companies-civil society organizations (Aguilar 2016, 90).

Therefore, it is assumed that the State loses its monopoly in the domain of economic norms and regulations, internal, national and sub-national policies, or if preferred, the existence of a very thin line between internal and external is recognized. As a consequence, it is coexisted in a context full of actors, justifying it from the mandatory authorization by the International Financial Organizations (Rosenau 2006, 15).

The following has been to see how systematically countries have been pressured by international organizations to implement sectorial public policies in accordance with the requirements of financial organizations such is the case of the International Monetary Fund, the World Bank, the Organization for Cooperation and economic development. The policies followed coincidentally addressed the industrial reconversion required by the change in the international context whose backdrop was globalization. These instruments were the expression of different internal documents, such as the Oslo Manual and Frascati (Rosenau 2006, 21) whose purpose was to standardize the concept and promote the increase of research and development, among other aspects of Societies in crisis.

The IMF, did not generate a concept on innovation as such, but did focus its efforts on guiding and executing its public policy technical assistance to national governments. It did so, through the impulse of an economic policy focused on the financial market and its other instruments such as fiscal, monetary and sectoral policy. The strategy that followed showed dyes that could easily be part of what is now known as democratic innovation by proposing the application of governance that would meet the demands of adapting the political context of the crises generated after the thinning of the State. The implementation of the "recipes" of international financial organizations as democratic innovation was assumed unjustifiably. From their perspective, they were designed to meet 
social demands in states unable to establish efficient and competitive policies of the new reality, after the fall of socialist governments.

Innovation for the OECD "is an interactive process driven by the perception of an opportunity provided by a new market and / or new service and / or technological advancement" (2010, 35). In accordance with the above, democratic innovation may fit the definition despite the lack of precision within it.

For its part, the World Bank seems to have a more "social" position on the concept of democratic innovation called Inclusive Innovation. Inclusive innovation involves linking with different actors in specific contexts. Those who should play a fundamental role in the processes of learning and collaborative innovation created within the target population (2018). Of course, the above requires a separate analysis.

On the other hand, as far as Mexico is concerned, both poverty and marginalization have increased, a situation that can be attributed to an unequal distribution of income. However, the World Bank insists on pointing out that "innovation can be a key factor not only to increase productivity and competitiveness, but also to reduce inequality and poverty" (BM, 2013). His insistence has taken the concept even further through the recommendation of programs to be implemented by national governments, with few visible results.

It is worth approaching a slope within the existing democratic innovation in a framework of the improvement of the governmental exercise, we refer to social innovation. According to the OECD, it consists of: "[...] in finding new ways to meet social needs, which are not adequately covered by the market or the public sector $[\ldots]$ or in producing the behavioral changes necessary to solve the great challenges of society [...] training citizens and generating new social relationships and new models of collaboration. They are, therefore, at the same time innovative in themselves and useful to enable society to innovate $[\ldots]^{\prime \prime}$ (2010, 45). It would correspond, therefore, to devise or utter actions and facts that pay in giving creative answers to the problems and needs of the community. In this context, public actions and policies can aim to have better results and in turn optimize the use of resources dedicated to them according to Ortiz, (cited in Soto 2018). 
In the strictly political field, democratic innovation refers to formal methods other than representative mechanisms. These have been developed to involve citizens in collective decisions. Therefore, include them in the political sphere that help to change governmental structures and processes in order to improve them (Montes de Oca 2018). In that sense, innovation is aimed at deepening democracy by increasing citizen power, taking into account that there is a deficit in terms of quality and social justice by becoming incentives to participate (Aedo 2014). In this same context, the concept of democratic innovation appears in the sense of being: a planned change. Political reforms are associated with the social objectives that politicians consider a priority, in various countries they make changes in their political and governmental character (Cox, Booth, Dunne 1999). This leads us to ask ourselves the following question about social innovation: what role does democracy play for social changes? Through the difference and decrease in the space occupied by politics, various social subsystems established in a relatively autonomous way can be explored. This implies the preexistence of political conditions within the scope of the market, against the problems facing society in areas such as education and health, after the adjustment policies that led to what Touraine points out as the "demodernization" of the State (Touraine 1997).

Social innovation is a developing status, with increasing importance in some regions of the world, mainly Europe and Latin America. This type of innovation involves placing people at the centre of the action, they would be the engine of the model, by positioning themselves as innovators. The current political transformation would be linked to structural changes in the administrative and institutional sphere. Undergoing governance actions as a political procedure in decision-making and, in turn, promoting citizen empowerment through market regulation. This implies being able to drive the government's responses to social welfare. According to Brunner (2011), democracy has historically been the political epicentre where there have been a series of social changes. Today, the above is evident by assuming, increasingly, the form of political organization that ensures the change "of" and "from" societies. It is worth asking about what is the role of governance in this process of administering policy to reconcile the 
genuine interest of societies to participate in decision-making from the political sphere and not merely as an administrative process? (cited in Soto 2018, 7).

At present, democratic innovation has allowed political systems to consider new relationship schemes between citizens and their political representatives, by admitting a certain reunion between politics and society. This leads us to the democratic innovation described by Lissidini (2014) as the use of forms and mechanisms that allow citizen participation, by transcending and questioning the ways of doing politics overcoming what is historically determined by organizations such as unions or parties.

Consequently, democratic innovation essentially refers to formal and informal mechanisms by facilitating the participation of citizens in the identification and resolution of their demands through agents and political actions, by being able to propose their own social and political agendas. According to Soto (2018), they also appear, in the field of management, in accordance with laws that give rise to processes of greater inclusion, participation and transparency. In the case of citizen initiatives present in governments with specific initiatives (such as the call for citizen assemblies or the activation of regulated management mechanisms with legal-administrative support), the important thing is to know that the object of democratic innovation must be the overcoming of the crisis of representative democracy by empowering citizens.

\section{THE INEQUALITIES BALANCE OF THE "DEOCIALIZATION" OF THE STATE}

In the midst of the fundamentally economic globalization process, used as a framework for the implementation of a system focused on international markets, a series of shock policies began to be used to address the state crisis, dictated by international financial organizations, always focused on giving way to the supply of exchange of goods and services, mainly of a financial nature. From which the argument about the need to create the mechanisms that ensure the 
governance of the modern state was exceeded due to its inefficiency as a manager of the goods and services of increasingly demanding societies.

Since the beginning of the 21st century, governance has offered the perfect framework for the implementation of a series of State adjustments. It is fundamentally sought to catapult innovation always from a discursively democratic system in opposition to the defeated socialist system and put out of force. In the midst of this new discourse where a new practice is proposed within "democratic progressivism". The scheme followed by CSOs acquires the symbol of a balance between political, economic and social power. The insertion of a part of CSOs, fundamentally in the form of NGOs, alongside governments and the business class, crystallizes as the most daring and pristine piece of a "good practice" within governance. It will mature to become a democratic innovation, the most relevant practice in "good governance".

CSOs in their role as providers of goods and services demanded by society complements the exercise of governments in the context of governance. However, this has coincided with the new role of the State in relation to social demands in the context of a decrease in social spending. A consequence of this process is the redefinition of policies and an acceleration in the transfer of functions and obligations of the State to private companies, often arranged in the form of NGOs, which attempt to fill the gaps left by welfare policies (Irarrázaval 1990, 170-186).

The recurring economic crises that began steadily from the eighties of the last century, revealed the social problems in most countries in Latin America, including Mexico. This situation gave way to the establishment of a new form of exogenous organization to governments, that is, NGOs are given as a manager and administrator of public policies (Teixidó and Chavarri 2000, 21), thus allowing new forms of attention to the demands. It gives way to the convergence of business interests, who at the same time acquires legitimacy from the State through practices from the New Public Management where governance seems to be the sieve through which the relationship between CSO and market is created thereby gaining its naturalization card.

Through this new relationship, large amounts of money is mobilized, new recruitment strategies are started, foundations are created for this purpose, 
positioning themselves quickly (Teixidó and Chavarri 2000, 21-23). Such is the case of foundations such as Teletón, the Mexican version saw the light in 1997 focusing its objective on the disabled population, specifically rehabilitation and its integration into society.

Among the traditional actors of liberal political systems, gradually affected by animosity, are political parties, trade unions, inter alia. Historically seen above all in Latin America as articulators and drivers of social demands. They maintained their catalytic role of social changes, for a long time virtually the entire 20th century. With the state crisis they have simply been losing it, new forms of citizen participation and representation are occupied by NGOs (Huneeus 2014). The new forms of organization show a resounding break, most of the time between traditional political parties and civil society. The crisis of the State brought with it the reinvention of citizen participation in the framework of governance, thereby acquiring its own characteristics. This is how a transparent relationship between NGOs and companies has been reached, increasingly aimed at developing actions for the management and administration of goods and services in response to the demands of society (Irarrázaval 1990, 156-158), thus replacing the functions of the State.

Since the return or democratic opening in Latin America and Mexico, the participation of organized civil society has been increasingly seen. A fact that has been used to place new demands on the political agenda according to the interests of NGO funders, legitimized from the "good practices" under the shelter of governance. In the current scenario, the dimension of the State in this new phase considers the actions of organized civil society as fundamental for democratic consolidation and with it the assurance of citizen participation. However, it attracts attention, while worrying, the translation of social demands into public policies.

The way of carrying them out contradicts democratic advances, at the time of the management of resources within the framework of competitive funds, such as subsidies or grants. By increasingly using the financing scheme and being recipients of the granting of public resources in exchange for providing services to NGOs that meet demands for services and care for children, youth and health, often linked to market interests (De la Maza 2005, 169). In other words, 
we are facing the immersion of the business group to the field of public policy implementation by granting them under this scheme: concessions, tax relief, incentives, contracts and licenses.

The State, as noted above, in the current governance scheme, has ceased to be a donor in its increasingly questioned relationship with NGOs, to give way to a new business model with them. He has become a true service contractor with them, now legitimized with horizontal governance arguments. While it is true that the linkage scheme has given way to a new scenario in relation to CSOs, in turn they mean more mechanisms of action, with greater financing transferred from the State to the business community. Unfortunately they also give rise to opaque processes, in terms of transparency little progress is made in the objectives and processes that are carried out.

The link established implies, in accordance with the work presented by the Institute of Communication and Development (2014) where it states that, "they conform to the role of public policy enforcement agencies and social service providers, to the detriment of organizations second grade (networks, collective) and CSOs for the promotion of rights and advocacy "(p. 26). Significantly affecting the actions aimed at combating the inequalities generated within the framework of the new system of "de-socialization of the State" with an impact not only in those economic fields, but basically in those of a social nature, against exclusion and discrimination in any of its forms.

One more of the negative consequences of the new State-CSO relationship, within the framework of governance, lies in the absorption of these organizations by the State. Many NGOs have become mere subsidiaries that normalize public policies through their implementation and not necessarily through legitimate attention to society's demands. This situation has damaged the nature and purposes of CSOs, a kind of kidnapping has been generated by the central governments of these organizations, with the consequent loss of autonomy, and their pre-eminence as a social actor (Acción 2009). On occasion, when governments, whether national or sub-national, play an important role (if not leading) in the transfer of public assets to NGOs, their actions can be conceived as a kind of manoeuvre, as support and strengthening of government towards institutions benefiting from these programs arising from a new 
relationship. This causes CSOs to direct their functions towards government objectives and not social needs, thereby losing their critical potential towards the State (De la Maza 2005, 179)

\section{CONCLUSIONS}

In conclusion, it is worth reflecting on some aspects in relation to governance as a product and tool aligned with the hegemonic market systems' interests in the post-industrial era. Conceptually speaking, the canons that guide it appear to be aligned with those of the market. By working as the central organizing principle of the system, both for the State and for CSOs, the rules that prevail in the market penetrate the public administration of the State, under the argument of making it more efficient and competitive.

It is in this logic that international initiatives used by financial agencies and agencies of the United Nations are generated to apply them in national and subnational systems in favour of better management in the democratic innovation scheme. In this logic, legal baggage is implemented through international treaties, conventions and protocols, as well as local laws, decrees and secondary laws that apparently try to give certainty and legal certainty, (Montes de Oca 2018, 287-291). This has allowed establishing the mechanisms through which governance acts in the field of inequality. The same happens in almost every human activity within the governments of every State in the process of "demodernization" today.

The contextualized market system in the post-industrial era and the theories that underlie it prefigure it in the system only in its economic dimension, stripping the social character of people. They make it appear simply as a homo œconomicus (Ibáñez 2012), from which the eco-space conducive to the development of today's hegemonic system is built. In globalization, where the free transfer of goods and capital is imperative, not that of people, it deepens the inequality gap, initially those of an economic nature, but inevitably end up deepening the rest of the inequalities of societies increasingly "demodernized." 
Currently, the system, as said before, privileges the market economy. All the time has been insisted on the abolition of economic and commercial borders, not political borders. It insists on making the concept of nationality disappear, favouring the construction of ideas in favour of an apparent universal citizenship, hence the replacement of the notion of "international" with that of "globalization" is not surprising. It is a very subtle change amid the homogenizing culture that the market system requires. Where individuals become cosmopolitan, uprooted, interchangeable, disposable beings (Touraine 1997).

In that same logic, the political level within the modern State has been designated as the "enemy" of the current hegemonic system - even though it is systematically denied. From a modern perspective of society, the market function should be subject to sovereign conception, however, it is not so. Currently, the economy bursts in the first place, giving rise to the dispossession of the socio-political role of the State. The intention seems to be his disappearance in favour of a sovereign market. In politics it cannot be forgotten that there is a priority choice over all others, and the market is no exception. Therefore, the "common good" should be a social priority speaking above the interests of the subjects. But for those who defend the system based on a market economy, the government of the people has become the organization of the mechanisms in support of the terms of trade. Social relations have been commercialized, at the level of objectification of the individual. Its existence is only explained and accepted in relation to its purchasing capacity and not as it was previously based on its productive capacity. The private is privileged over the public, people are interested if, and only if, they can be part of that market, nothing that is not profitable can acquire enough interest to be preserved (Brown 2010).

According to Brown (2010), the protective State, guarantor of the "common good," is being destroyed to become a "managerial State" through governance practices and its "democratic innovations." It is only called, as noted, to guarantee the necessary scenarios for the improvement of the free market. The State is located not to impose policies close to a conception of the "common good", on the contrary, it seeks to apply the management model built from the 
"governance", the "good governance" to be precise. In fact, it seeks to hide in this neologism the oligarchic, antidemocratic and globalized system, which it serves. In other words, for the new actor in governance, that is: the agents of the international market in neoliberalism. Its objective is clear, it is about intervening in the political space, of setting its functioning to serve the interests of the market system that seeks to reproduce itself (Brown 2010; Ibáñez 2012) It is about the different spaces of management and political power working in the "governance governance" scheme and taking its elements from the "capitalist", "modern" business model, directed towards new "management models", as Ibáñez (2012) points out "with its program contracts, its results evaluations, its work for objectives, its promotion of autonomy, its delegations of power, its flexibility of the lines of command, its incitements to participation and accountability, its emphasis on performance and competitiveness, etc. "(: 23) that is to say from the democratic innovation of its institutions, who certainly do not write down in their agendas the fight against inequalities.

\section{REFERENCES}

- Abreu, José Luis. 2011. “Innovación social, conceptos y etapas". Daena: International Journal of Good Conscience, 6(2),134-148. (October 2011) http://www.spentamexico.org/v6-n2/6(2)134-148 (April 4, 2019).

- Aedo, Camilo. 2014. Innovación Democrática: Empedramiento Estudio comparado de ocho experiencias de presupuesto participativo en Chile. Tesis. Barcelona: http:/ / www.tdx.cat/bitstream/handle/10803/285354/cav1de1.pdf;jsessio nid=23C42BDB (January 12, 2019).

- Acción. 2009. “Dilemas y desafíos democráticos fundamentales en la región: síntesis del estado de la cuestión en algunos países". Seminario Internacional Democracia en América Latina: límites y posibilidades de cambio. Santiago de Chile: Acción http://mesadearticulacion.org/wpcontent/uploads/2009/09/5.pdf (May 10, 2019). 
- Aguilar, Luis. 2016. El estudio de las políticas públicas. México: Fondo de Cultura Económica.

- World Bank. 2018. Definición de Sociedad Civil, (en línea) disponible en http://www.bancomundial.org/es/about/partners/civil-society. Washington: World Bank. (April 23, 2019).

- 2013. Promueve innovación inclusiva para el crecimiento sostenible. Washington: World Bank.

- Bloj, Cristina. 2009. El "presupuesto participativo" y sus potenciales aportes a la construcción de políticas sociales orientadas a las familias. Santiago de Chile: United Nations/CEPAL.

- Brown, John. 2010. “De la gobernanza o la constitución de la política del neoliberalismo". Sociología crítica, artículos y textos para el debate y análisis de la realidad social. WordPress https://dedona.wordpress.com/2010/05/13/de-la-gobernanza-o-laconstitucion-de-la-politica-del-neoliberalismo-jhon-brown/ (June 10, 2018).

- Brunner, José Joaquín. 2011. “Regímenes de gobernanza universitaria: un estudio topológico y de tendencias". El Conflicto de las universidades: entre lo público y lo privado. Santiago de Chile: Universidad Diego Portales.

- Cox, Michael.; Booth, Ken.; Dunne, Tim. (eds.) 1999. The Interregnum: Controversies in World Politics, 1989-1999. Cambridge: Cambridge University Press.

- De la Maza, Gonzalo. 2005. Tan lejos, tan cerca. Políticas públicas y sociedad civil en Chile. Santiago de Chile: LOM Press.

- Echeverría, Bolívar.2008. "Un concepto de modernidad". Contrahistoria, 11(8) 2008. México: UNAM.

- Espejel, Jaime. 2013. Los fundamentos político-administrativos de la gobernanzaMéxico: Fontamara.

- Friedmann, Georges. 1977. La crisis del progreso. Madrid: Laia.

- Fukuyama, Francis. 2015. El fin de la Historia y otros ensayos. Madrid: Alianza Editorial. 
- Goldfrank, Benjamin. 2006. "Los procesos de 'presupuesto participativo' en América latina: éxito, fracaso y cambio". Revista de Ciencia Política, 26 (2, 2006): 3-28. Santiago de Chile: Pontificia Universidad Católica de Chile.

- Hernández-Ascanio, José et al . 2016. “El concepto de innovación social: ámbitos, definiciones y alcances teóricos" Revista de Economía Pública, Social y Cooperativa, 88 (12, 2016): 164-199 CIRIEC-Spain.

- Holloway, John. 2002. Cambiar el mundo sin tomar el poder, el significado de la revolución hoy. Puebla: Herramienta-BUAP.

- Huneeus, Carlos. 2014. La democracia semisoberana. Chile después de Pinochet. Santiago de Chile: Taurus.

- Ibáñez, Tomás. 2012. La Gobernanza: pieza clave del neoliberalismo avanzado. Madrid: Debates, LP 73.

- Instituto de Comunicación y Desarrollo. 2014. “Estudio Regional sobre mecanismos de financiamiento de las organizaciones de la sociedad civil en América Latina". Mesa de Articulación y sus aliados del sur aumentan sus capacidades de incidencia y diálogo con gobiernos y sector privado 2013-2014. Agosto 2014. Santiago de Chile. http://accionag.cl/wpcontent/uploads/2015/02/Estudio-Mecanismos-de-Financiamiento-ONGAmerica-Latina-y-el-Caribe.pdf (February, 20, 2019).

- Irarrázaval, Ignacio. 1990. "Promoción del desarrollo social privado a nivel local: una propuesta". Estudios Públicos. 38 (1990): 149-192.

- Krahmann, Elke. 2019. "National, Regional and Global Governance: One Phenomenon or Many?", Global Governance, 9, 3 (2003): 323-346. https://www.jstor.org/stable/27800486 (February, 02, 2019).

- Lissidini, Alicia., Welp, Yanina. y Zovatto Daniel. 2014. Democracias en Movimiento. México: UNAM.

- Montes de Oca, Laura. 2014. “¿Innovaciones democráticas? Análisis del Consejo Consultivo de telecomunicaciones en México". Revista mexicana de sociología, 76(2):

287-

320.http:/ / www.scielo.org. $\mathrm{mx} /$ scielo.php?script=sci_arttext\&pid=S018825032014000200005\&lng=es\&tlng=es. (May, 22, 2019). 
- Morales, Alfonso. 2008. "Claves para comprender la innovación social". La innovación social, motor de desarrollo de Europa, Sevilla: Socialinnova (2008) 13-38.

- Moulaert, Frank., MacCallum, Diana, Abid Mehmood, Abdellllah Hamdouch. 2010. Social Innovation: Collective action, social learning and transdisciplinary research, London, Katarsis, EU's Framework Program 6, Final Report.

- Mulgan, Geoff. (2006): “The process of social innovation". Innovations, 2(1), 145-162. Junio(20) https:// doi.org/10.1162/itgg.2006.1.2.145

- OECD. 2008.Oslo Manual: Guidelines for Collecting and Interpreting Innovation Data. París: OECD/European Comission.

- _ 2010. Interfutures. Facing the Future: Mastering the Probable and Managing the Unpredictable, París: OECD.

- Requena, Carlos. 2014. Gobernanza, retos en la relación Estado-Sociedad. México: LID.

- Rosenau, James. 2006. The Study of World Politics. New York: Routledge.

- Simmel Georg. 1987. Philosophie de l'Argent. Paris: Presses Universitaires de France.

- Soto, Francisco. \& Felipe, Viveros. 2016. "Las Organizaciones de la Sociedad Civil desde su marco jurídico e institucional: Configurando un actor social". Tercer informe Proyecto Sociedad en Acción. Santiago: Centro de Políticas Públicas UC y Fundación Chile más Hoy.

- Teixidó, Soledad \& Reinalina Chavarri, Andrea Castro (eds.). 2000. La acción filantrópica como un elemento de la responsabilidad social. Santiago de Chile: PROHumana.

- Touraine, Alain. 1997. ¿Podremos vivir Juntos? Iguales y diferentes. Madrid: PPC Press.

- Zenteno, Blanca \& Armando, Osorno. 2015. Gobernanza derechos humanos y grupos vulnerables. México: Juan Pablo Editores. 